\title{
Hedge funds: Ten years of private client investing - is it still time to invest?
}

\author{
Pascal Botteron \\ Hedge Fund Investments, Deutsche Bank (Suisse) SA, PI. des Bergues 3, 1211 \\ Geneva 1, Switzerland. \\ Tel: +4122 73907 91; Fax: + 412273907 84; E-mail: pascal.botteron@db.com \\ Received (in revised form): 11th September, 2006
}

Pascal Botteron is Lecturer at the University of Zurich and Head Hedge Fund Investments for the International division of Deutsche Bank's Private Wealth Management. I would like to thank my colleagues at Deutsche Bank, Martin Keller, Svein Floden, and Kimberly Hain, for valuable discussions and comments. All views expressed in this article are mine.

\section{Practical applications}

Hedge funds have been subject to a great deal of negative press over the last 10-15 years. Some of this negative press was probably justified in the 1990s because the hedge fund industry was emerging and thus experiencing symptoms of a construction phase. However, following the arrival of professional investors to the industry, such as fund of fund managers and pension funds, among others, the hedge fund space has become increasingly institutionalised and has experienced dramatic changes. Given the evolution of the hedge fund arena, we felt it was appropriate to revisit all the arguments usually mentioned in the negative press and examine whether they continue to have any validity. We refer in this paper to a wide range of industry statistics and studies to show what arguments are still valid and what arguments are no longer founded. We then highlight important issues to consider when investing in hedge funds in today's environment.

\begin{abstract}
This article examines and addresses the arguments presented against the hedge fund industry in past years. We try to identify the source of each argument and verify whether these arguments are still valid. We find that a majority of these arguments are largely unfounded, although some still apply. The conclusions we draw from this analysis allow us to give some direction as to the factors that should be considered in
\end{abstract} Derivatives Use, Vol. 12 No. 4, 2007, pp. 301-313 (C) 2007 Palgrave Macmillan Ltd $1357-0927 \$ 30.00$
Keywords: hedge funds; portfolio construction; due diligence

\section{INTRODUCTION}

Following the lead of large family offices, some that have traditionally invested up to 75 per cent of their liquid assets in hedge funds, large private banks began to distribute hedge fund products to their clients in the mid-1990s. Since then, the hedge fund space has fared well, providing attractive returns and experiencing tremendous growth, all with only a few negative surprises (LTCM, Manhattan, Lancer and Bayou). 
However, this handful of isolated

disappointments have generated strong negative

press for the entire hedge fund space,

highlighting the dangers of investing in this

'new' asset class. Even as many of the points

presented by the press had some validity during

the 1990s, much of the negative press on hedge funds today is no longer warranted. This paper aims to revisit the once valid criticism and

concern presented by the press, determine which items continue to be of concern, and identify those that are no longer valid given the developments and evolution of the hedge fund arena. Based on this exercise, we will also draw conclusions on the future of hedge fund investing. ${ }^{1}$

\section{Why the negative press?}

During the 1990s, the press was very negative on hedge funds. Journalists highlighted the following: the lack of regulation for hedge funds,

\section{Box 1: Hedge funds versus equity indices and behaviour in a period of crisis}

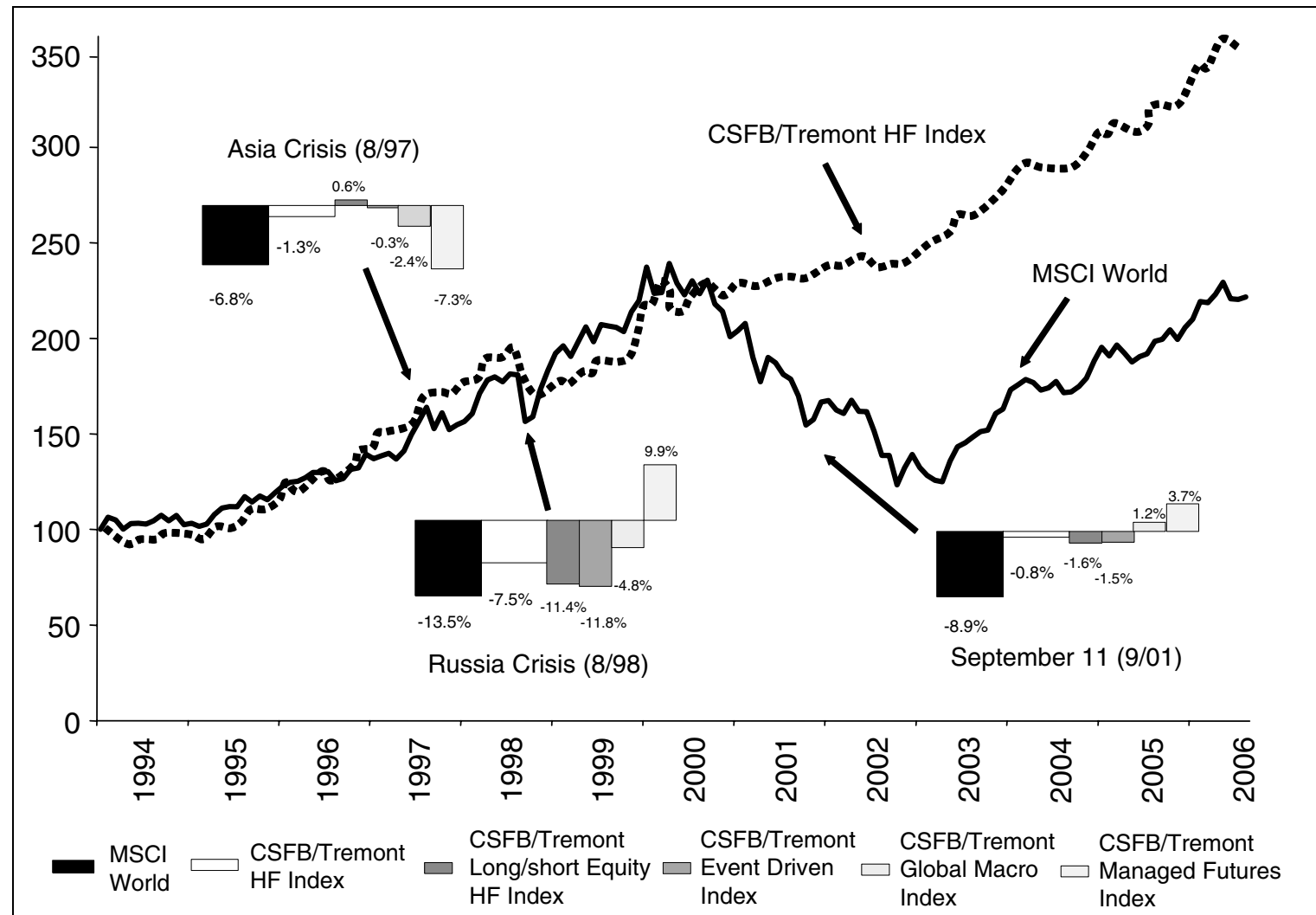

Historically, hedge fund managers are in general better protected in a period of crisis than pure traditional asset classes. Major hedge fund strategies smoothed the downside when equity markets (as expressed by the MSCI World) dropped sharply. 
the risks of blowups (some sources cited up to 20 per cent bankruptcy rates), the lack of transparency hidden behind black boxes, the capacity issues in the hedge funds industry, the low volatility that does not reflect the risks of the industry, the high correlation of hedge fund managers to equity markets in up and down markets, the lack of diversification versus equity and bond markets, the high fees charged by these managers and the relative illiquidity of hedge funds. Unfortunately this negative press, some of which has been blown out of proportion, has led to many misconceptions surrounding hedge funds and a misunderstanding of the general space. Some of these misperceptions are still present - even if a posteriori, hedge funds have generated a higher and more stable return, particularly during periods of crisis (Box 1).

In the mid-1990s, hedge funds were considered by many as a 'new' asset class, difficult to understand and only accessible to a small club of private investors, including family offices and HNWIs. ${ }^{2}$ At that time, the industry was relatively small with assets under management below USD 200 billion (today, assets under management are estimated at USD 1.3 trillion). Hedge fund managers acquired assets based on their performance and reputation. Investors often made investment decisions based on word-of-mouth recommendations made by their peers without conducting any due diligence per se. The lack of formality in the decision-making process of investors enabled hedge fund managers to operate with very low transparency requirements. This 'black box' element of hedge fund investing made for a very misunderstood industry, raising severe doubts from the press and public regarding the soundness of the hedge fund space. Many of these doubts have been quelled over time as hedge funds have delivered on their promise to deliver superior riskadjusted returns with very few casualties along the way. However, occasional bankruptcies and short periods of underperformance cause investors and the press to revisit fears from the past, reigniting the negative press from the 1990s. This begs the question, is all the negative press warranted? Perhaps ten years ago, many of the fears surrounding hedge funds were justified to some degree; however, the hedge fund industry has evolved dramatically in the past decade, making many of these fears unfounded. Let us examine some of the negative arguments in the next paragraphs.

\section{Negative press: Fact versus myth}

\section{Hedge funds are unregulated, lack of transparency and tend to 'blowup'...}

The outstanding performance of hedge fund managers during the beginning of the 1990s (an average of 14.1 per cent annual return for a volatility of 6.8 per cent according to the HFR Index for 1990-1995) made a strong advertising case for this industry, which saw massive asset inflows not only from existing investors, but also from institutional investors and other professional asset managers such as funds of hedge funds. Fund of funds managers, having inherited strong due diligence requirements coming from the mutual fund industry, began applying demanding due diligence principles based on strict procedures in order to obtain a high transparency/understanding of hedge fund organisations (Box 2). This marked an important shift in the industry as professional investors started to allocate funds only in managers who met strict due diligence requirements in terms of 


\section{Box 2: The summary of due diligence}

Choosing either a hedge fund or a fund of hedge funds involves hard work. Due diligence questionnaires typically contain more than 300 questions on strategy, compliance issues, etc. The risks under scrutiny are the same as those analysed by risk managers in other financial firms making trading decisions:

- Strategy risk - Inadequate formulation/application of a strategy.

- Market risk - Change in a market variable. Can have a direct or an indirect effect.

- Credit risk - Default by a counterparty.

- Operational risk - People, process, management or system failures; model risk; legal; external; compliance failure, etc.

- Liquidity/treasury risk - Ability to convert into cash.

Moreover, the management team of a hedge fund is typically very small relative to that of any other type of financial institution. Hedge funds outsource as much as possible, so a risk analysis must also cover the agents that service the hedge fund, the prime brokers and other transaction and reporting organisations. As they say in another context, there is no substitute for diet and exercise. Facing a small investment operation composed of a limited number of personnel supporting a few managers, an investor must be very comfortable with how the managers deal with risk. We give the due diligence issues in their order of importance.

- Incentives - Has the manager invested a significant portion of his personal fortune in the fund?

- Risk control well in hand - Has the manager set up an independent risk control function in the back office? If not, corporate governance and compliance problems can occur, there are potential risks of fraud, wrong NAV computations, model risks, breach of limits, etc.

- External validation - Does an auditor regularly review the manager? Can we see a copy of the most recent report?

- Management skills - Has the manager managed people or a department in the past? If not, has an experienced $\mathrm{COO}$ been hired?

- Truth in advertising - Can we verify the references of the manager? Were effective background checks used in the selection of his staff?

- Apparent performance - Can the manager provide a back testing analysis of what the performance has been in the past?

Unfortunately, there is more once the investment is made. Things might go wrong, and you have to monitor activity very frequently. Once again, here are the considerations:

- Incentives - Is the manager reinvesting a significant portion of his personal profits in the fund?

- Follow-the-smart-money-out principle - If other investors are pulling out, this may be a signal that something may go wrong.

- Management skills - If there is a turnover in the number of employees in the fund, consider clearing out.

- Consistency of activity - If the manager enters investment areas outside his original demonstrated skill, ask why these should prove profitable. If the answer does not sound too convincing, this may be problematic.

- Performance record - There is some evidence in the available record that top quintile and bottom quintile performance tend to persist. Draw your own conclusions from this. 


\section{Box 3: Hedge fund bankruptcy evidence}

Christory, Daul and Giraud (2006) have gathered data on hedge funds defaults occurring between 1994 and 2005 and have compared them to the hedge fund space (defined for the purposes of this study as all hedge funds listed in seven major databases). They found a total number of 109 defaults over the past 11 years. Comparing the number of annual defaults with the total number of hedge funds identified by the researchers, we found a bankruptcy rate ranging between 0.08 and 0.52 per cent during this period, the highest rate corresponding to 1998 when 10 hedge funds defaulted in the universe of 1917 identified hedge funds. Among the interesting results of this study, the authors found that more than 50 per cent of defaults are due to a fraud and only 33 per cent due to financial issues. The research shows that frauds have a tendency to occur among small managers ( $<\$ 100 \mathrm{~m}$ of assets), while defaults linked to operational issues have a tendency to appear in larger organisations $(>\$ 500 \mathrm{~m}$ of assets).

Box 4: Growth of hedge fund industry/growth of capital market activity - no evidence of capacity issues at the global level

\begin{tabular}{|c|c|c|c|c|}
\hline & 1990 & 1995 & 2000 & 2005 \\
\hline Size of Equity Markets & $8.9 \mathrm{tn}$ & $17.1 \mathrm{tn}$ & $31 \mathrm{tn}$ & $44.5 \mathrm{tn}$ \\
\hline HF Industry $\star \star$ & $0.4 \mathrm{tn}$ & $0.2 \mathrm{tn}$ & $0.5 \mathrm{tn}$ & $1.1 \mathrm{tn}$ \\
\hline \multicolumn{4}{|l|}{ Capital Markets } & $2,5 \%$ \\
\hline \multicolumn{5}{|c|}{$\begin{array}{l}\star \text { Source World Federation of Exchanges } \\
\star \star \text { Source HFR }\end{array}$} \\
\hline \multicolumn{5}{|c|}{$\begin{array}{l}\text { Hedge funds still represent a small portion of global capital markets. It is worth mentioning that } \\
\text { hedge funds use leverage and that the figures reported by HFR for the hedge fund industry are thus } \\
\text { underestimated by a factor of around } 2 \text { to } 3 \text {, which is the average leverage used by hedge funds. } \\
\text { However, capital markets are just estimated by equity markets in these statistics and, thus, do not } \\
\text { include derivatives, bonds, commodities, etc. All in all, today hedge funds still represent a very low } \\
\text { portion of capital markets that probably does not exceed } 2 \text { per cent. }\end{array}$} \\
\hline
\end{tabular}

transparency and risk management. These changes saw due diligence analysts acting as regulators. This has been healthy for the industry, which saw a very small number of true blowups (less than 20 per annum in an industry of at least 6,000 managers according to
Christory, Daul and Giraud) over the past three years (Box 3). Moreover, a blowup has not necessarily resulted in investors losing everything, with many investors losing 20 to 40 per cent of invested assets according to industry professionals. $^{3}$ 


\section{Hedge fund strategies suffer from capacity constraints...}

As more managers enter the hedge fund space, there is increased pressure for managers to perform well. Some pure arbitrage strategies such as merger arbitrage and convertible arbitrage have struggled as new entrants have crowded out deal opportunities and margins. These managers have seen their double-digit annual returns decrease to single digits and in some cases negative returns. This difficult time saw the disappearance of some hedge funds or the mutation of some others into multi-strategy managers. Multi-strategy managers are no longer applying one unique strategy but rather a group of strategies, allocating their assets to the best opportunities presented in any given moment. Also, the evolution and growth of capital markets (credit, securitisation, emerging markets, activism, liquid private equity, etc.) have created new opportunities for the hedge fund industry, which as a whole does not suffer from capacity issues (Box 4). In summary, it is fair to say that some strategies applied in small markets are suffering from capacity issues; however, at the same time, thanks to the development of capital markets, a myriad of new opportunities are appearing on an ongoing basis.

\section{Volatility is a poor measure of hedge fund risks...}

Typically, volatility is used as a measure of risk in all asset classes, giving an indication of how much one can win or lose in a pre-defined interval. If measured by volatility, hedge funds are assumed to have relatively low risk as the volatility usually ranges between 2 and 10 per cent for an average of 5 to 6 per cent depending on the index selected. However, we must be careful in assessing risk based on volatility alone as volatility

\section{Box 5: Equity markets/CSFB L/S equity}

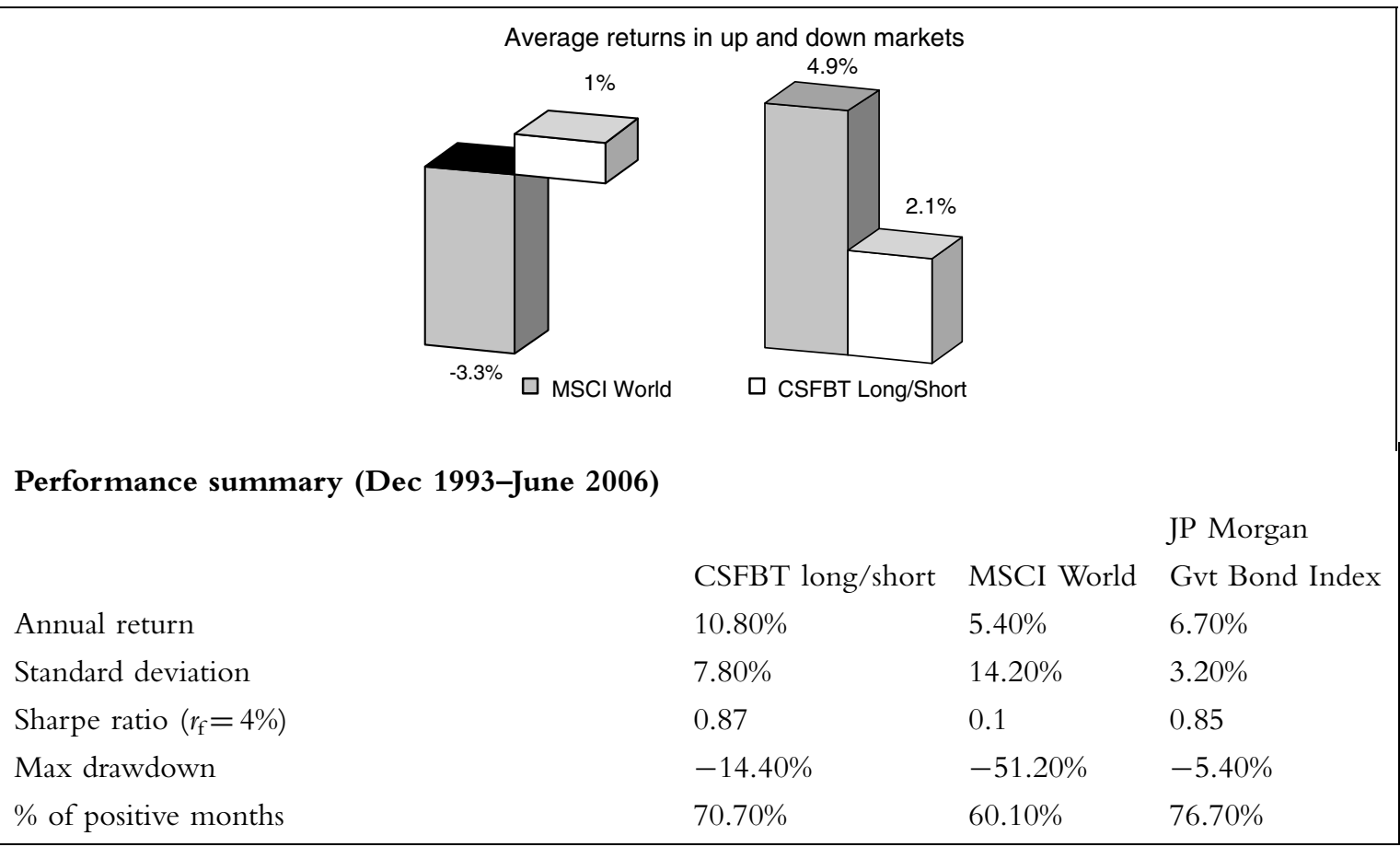


Box 6: CSFB LS leveraged versus MSCI World at the same level of volatility (13.6 per cent) with a cost of leverage fixed at Libor +100 bps

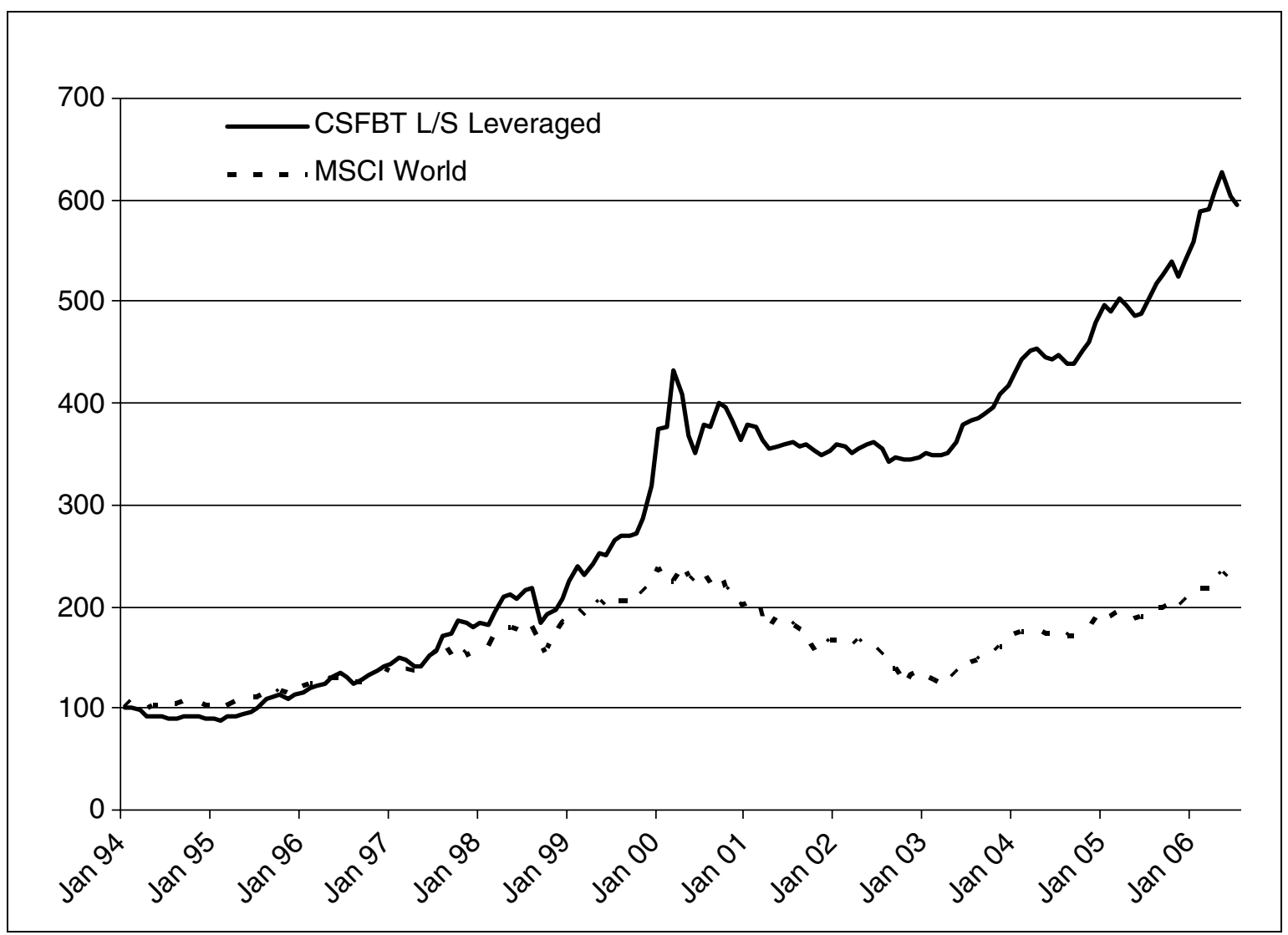

does not capture every element of risk, particularly as it pertains to hedge funds ${ }^{4}$

In order to understand risk, we need to consider the implied information content of volatility, which is the standard deviation of the portfolio. For conventional liquid assets, investors are comfortable with the notion that volatility estimates capture the essence of the investment risks they face. For liquid assets, investors are in a good position to assess a wide variety of risks - market, credit and operational - and factor these into their valuation of the assets. ${ }^{5}$ Their trading reflects this knowledge, and thus it is reasonable to argue that measured volatility captures this knowledge. By contrast, the measured return volatility of hedge funds contains only very limited information about the overall magnitude of the risks that an investor embraces by putting money into the fund. For hedge funds, reported return volatility is not the outcome of competitive prices driven by broadly informed traders and analysts. This volatility constitutes only the self-reported variability of the financial returns of the hedge fund strategy. No risk associated with the quality of the hedge fund (fraud, leverage, etc.) is contained in this measure of volatility. In other words, the volatility of hedge funds is probably correct but only provided that the due diligence conducted on the components of a hedge fund portfolio is outstanding. 
Table 1: Correlation between hedge fund strategies and equity indexes (1994-July 2006)

\begin{tabular}{|c|c|c|c|c|c|c|c|c|c|c|c|c|c|c|}
\hline & $\begin{array}{l}\text { CSFB/ } \\
\text { Tremont } \\
(\%)\end{array}$ & $\begin{array}{l}\text { Convertible } \\
\text { arbitrage } \\
(\%)\end{array}$ & $\begin{array}{l}\text { Ded. } \\
\text { short } \\
\text { bias } \\
(\%)\end{array}$ & $\begin{array}{l}\text { Emerging } \\
\text { markets } \\
(\%)\end{array}$ & $\begin{array}{l}\text { Equity } \\
\text { mkt ntrl } \\
(\%)\end{array}$ & $\begin{array}{l}\text { Event } \\
\text { driven } \\
(\%)\end{array}$ & $\begin{array}{l}\text { Distressed } \\
(\%)\end{array}$ & $\begin{array}{l}\text { E.D. } \\
\text { multi- } \\
\text { strategy (\%) }\end{array}$ & $\begin{array}{l}\text { Risk } \\
\text { arbitrage } \\
(\%)\end{array}$ & $\begin{array}{l}\text { Fixed } \\
\text { Inc. } \\
\text { arb. (\%) }\end{array}$ & $\begin{array}{l}\text { Global } \\
\text { macro } \\
(\%)\end{array}$ & $\begin{array}{l}\text { Long/ } \\
\text { short } \\
(\%)\end{array}$ & $\begin{array}{l}\text { Managed } \\
\text { futures } \\
(\%)\end{array}$ & $\begin{array}{l}\text { MSCI } \\
\text { world } \\
\text { index } \\
(\%)\end{array}$ \\
\hline CSFB/Tremont & 100 & & & & & & & & & & & & & \\
\hline Convertible arbitrage & 41 & 100 & & & & & & & & & & & & \\
\hline Ded. short bias & -49 & -25 & 100 & & & & & & & & & & & \\
\hline Emerging markets & 65 & 31 & -55 & 100 & & & & & & & & & & \\
\hline Equity mkt ntrl & 33 & 34 & -32 & 22 & 100 & & & & & & & & & \\
\hline Event driven & 67 & 57 & -63 & 68 & 36 & 100 & & & & & & & & \\
\hline Distressed & 58 & 49 & -62 & 59 & 34 & 93 & 100 & & & & & & & \\
\hline E.D. multi-strategy & 69 & 58 & -55 & 67 & 33 & 93 & 75 & 100 & & & & & & \\
\hline Risk arbitrage & 40 & 41 & -50 & 43 & 30 & 68 & 57 & 65 & 100 & & & & & \\
\hline Fixed inc. arb. & 44 & 53 & -8 & 28 & 12 & 39 & 32 & 43 & 14 & 100 & & & & \\
\hline Global macro & 86 & 30 & -14 & 42 & 22 & 38 & 31 & 43 & 14 & 45 & 100 & & & \\
\hline Long/short & 79 & 28 & -72 & 60 & 35 & 67 & 59 & 65 & 52 & 21 & 43 & 100 & & \\
\hline Managed futures & 15 & -13 & 11 & -8 & 13 & -14 & -10 & -15 & -15 & -6 & 25 & 2 & 100 & \\
\hline $\begin{array}{l}\text { MSCI The World } \\
\text { Index }\end{array}$ & 49 & 13 & -75 & 54 & 36 & 60 & 57 & 53 & 47 & 4 & 20 & 63 & -8 & 100 \\
\hline JP Morgan GBI & 17 & 10 & 11 & -12 & 15 & -6 & -1 & -10 & -6 & 12 & 27 & 5 & 32 & -8 \\
\hline GS commodity & 17 & 6 & -8 & 11 & 8 & 14 & 12 & 15 & 3 & 11 & 7 & 21 & 22 & 8 \\
\hline
\end{tabular}




\section{Hedge funds offer no real decorrelation benefits...}

Some have become particularly critical on hedge funds active in equity markets for their inability to outperform equities in bull markets and their frequent participation to some degree on down markets. In these cases, hedge funds have been criticised for their high fee structure $(2$ per cent management and 20 per cent performance fees). This observation seems to be correct at first sight when we look at Box 1, where we see that during the last bull markets, the MSCI World has slightly outperformed the CSFB/Tremont Index. However, this analysis must be put in perspective as historically, when equity markets have been positive, hedge funds have always been positive, and when equity markets have been negative, hedge funds were again positive (Box 5). All of this is with a lower volatility.

Now, let us imagine using hedge funds with the same level of volatility/risk as equity markets. In this case, hedge funds would significantly outperform equity markets (Box 6). However, comparing the two volatilities makes a strong assumption on the efficiency of the due diligence process.

It is true that the correlation between some reported hedge fund indices and traditional asset indices has been high for some hedge fund strategies but not for hedge funds as a whole. For example, Table 1 shows that the CSFB/ Tremont Index has a high positive correlation to the main international equity indices. Therefore, in some cases, hedge funds will not allow the investor to benefit from having a higher level of diversification in his or her portfolio. In fact, Table 2 shows that there are only a limited number of strategies that are uncorrelated to the markets (convertible arbitrage, fixed income arbitrage, global macro and managed futures). ${ }^{6}$ However, despite the fact that not all hedge funds offer decorrelation benefits, the ability of managers to capture opportunities in bull markets and to reduce their exposure in down markets (even and often in periods of crises) makes them very attractive to any investor portfolio. Finally, it is important to highlight that the correlation of a hedge fund index with a traditional asset index is not as relevant as the correlation of a specific hedge fund investment with other assets within an investor's portfolio. The appropriate diversification of any portfolio depends on the correlation of its specific components and must be analysed on a case-by-case basis. $^{7}$

\section{Hedge funds are expensive...}

One may say in this context that hedge funds are expensive, but it is important to keep in mind that hedge fund performance is always presented net of all fees. This is an industry practice, which has been adopted in order to show that these relatively high costs are justified. In summary, would one prefer to pay a hedge fund of $2 / 20$ per cent for a net of fees performance of 10 per cent or 1 per cent for a net of fees performance of 5 per cent? The high fees charged by hedge funds are probably justified, provided they are performing well. The discussion is more difficult for funds of hedge funds, which charge an additional layer of approximately 2 per cent (or sometimes $1 / 10$ per cent). This additional fee is justified in four cases. First, to gain access to talented managers who many investors cannot access due to their size and lack of industry network. Second, to gain a valuable layer of due diligence. Third, to access the talent of a fund of funds portfolio manager who actively manages the strategy and manager allocation of a 
Table 2: Stability of correlation overtime

\begin{tabular}{|c|c|c|c|c|c|c|}
\hline Benchmarks $^{\mathrm{a}}$ & $\begin{array}{l}\text { Breakdown } \\
\text { of style }{ }^{\mathrm{b}}(\%)\end{array}$ & $\begin{array}{l}\text { Correlation to MSCI } \\
\text { (Jan 94-July 06)/ } \\
\text { monthly data (\%) }\end{array}$ & $\begin{array}{l}\text { Period } 1 \text { correlation } \\
\text { to MSCI } \\
\text { (Jan 94-Dec 96)/ } \\
\text { monthly data (\%) }\end{array}$ & $\begin{array}{l}\text { Period } 2 \text { correlation } \\
\text { to MSCI } \\
\text { (Jan 97-Dec 99)/ } \\
\text { monthly data (\%) }\end{array}$ & $\begin{array}{l}\text { Period } 3 \text { correlation } \\
\text { to MSCI } \\
\text { (Jan 00-Dec 02)/ } \\
\text { monthly data (\%) }\end{array}$ & $\begin{array}{l}\text { Period } 4 \text { correlation } \\
\text { to MSCI } \\
\text { (Jan 03-Jul 06)/ } \\
\text { monthly data (\%) }\end{array}$ \\
\hline Convertible arbitrage & 6 & 13 & 22 & 21 & 12 & 29 \\
\hline Dedicated short bias & 0 & -75 & -57 & -82 & -80 & -73 \\
\hline Emerging markets & 5 & 54 & 29 & 69 & 65 & 73 \\
\hline $\begin{array}{l}\text { Equity market } \\
\text { neutral }\end{array}$ & 5 & 36 & 25 & 61 & 29 & 29 \\
\hline Event driven & 14 & 60 & 56 & 71 & 48 & 70 \\
\hline Distressed & 23 & 57 & 69 & 68 & 39 & 62 \\
\hline $\begin{array}{l}\text { Event driven } \\
\text { multi-strategy }\end{array}$ & & 53 & 19 & 68 & 48 & 66 \\
\hline Multi-strategy & & 16 & 6 & -24 & 44 & 68 \\
\hline Risk arbitrage & & 47 & -3 & 62 & 33 & 82 \\
\hline $\begin{array}{l}\text { Fixed income } \\
\text { arbitrage }\end{array}$ & 7 & 4 & 27 & 5 & -13 & 20 \\
\hline Global macro & 6 & 20 & 35 & 27 & -2 & 46 \\
\hline Long/short & 29 & 63 & 62 & 79 & 34 & 86 \\
\hline Managed futures & 5 & -8 & 17 & -6 & -53 & 45 \\
\hline $\begin{array}{l}\text { CSFB Tremont HF } \\
\text { Index (USD) }\end{array}$ & 100 & 49 & 45 & 59 & 33 & 79 \\
\hline
\end{tabular}

January 1994 to July 2006 is split into four periods. The first three periods are of three years and the last one is three years and a half.

${ }^{\mathrm{a}}$ The benchmarks are CSFBT indices.

b'TASS Research 2004. 
portfolio. Fourth, to access a specific competency in a region, strategy or theme that could not be easily captured by investing in a single hedge fund manager. There are, unfortunately, a range of funds of hedge funds that do not meet these requirements and, therefore, do not justify paying the additional layer of fees.

\section{Hedge funds are illiquid...}

The liquidity of hedge funds is almost always significantly less than that of any kind of tradable asset fund, and in some cases approaches the illiquidity of other asset classes such as private equity. However, most hedge funds have redemption periods between one and three months. Although liquidity may be an issue for some investors, it is a small price to pay for the attractive risk-adjusted returns offered by hedge funds.

\section{Hedge fund investing going forward}

\section{There are risks, but they can be managed}

As discussed thus far, the majority of fears surrounding hedge fund investing have not materialised. Nevertheless, there are some factors that should be considered by potential hedge fund investors going forward. Capacity may remain/become an issue in some strategies, but other opportunities are rising in capital markets. It is the responsibility of investors to monitor changes in the dynamics of strategies and to actively manage the allocation to strategies according to these changes. Like any institution, hedge funds have a risk of a blowup/ bankruptcy. Conducting extensive due diligence on all the components of the hedge fund portfolio greatly reduces this risk and makes the investment in hedge funds safer. Finally, hedge fund strategies have different correlations to each other and traditional asset classes; specialists estimate the number of hedge fund strategies applied by hedge fund managers to be higher than 30. Each of them has a different objective and, depending on an investor's existing portfolio, may or may not match an overall portfolio diversification objective. It is the responsibility of the investor to define what type of alpha contribution he or she expects from the hedge fund component of a portfolio.

\section{The importance of asset allocation}

How can we continue to achieve good returns? As we have seen above, a fraction of the industry is subject to capacity. Hedge funds themselves have the objective to generate positive performance in all market conditions, and thus the manager of any hedge fund portfolio must build his portfolio according to his or her personal views on the managers and on the strategies they operate. The majority of the so-called funds of hedge funds managers will tell you that they are both bottom-up and topdown, which is probably true. Bottom-up means that they identify the best managers, and topdown means that they overweight their favourite strategies. Manager selection is based on long discussions with managers and on the portfolio manager's ability to correctly evaluate the soundness of managers and their operations. Selecting the right strategy is based on the macro views of the portfolio manager who anticipates the future of the strategy. For instance, some strategies are affected by business cycles (eg event driven), by market volatility (eg equity market neutral) or by the number of deal opportunities in a pre-defined market (eg convertible 


\section{Box 7: Summary of Omega}

Considering mean and variance as the only variables for performance measurement may be misleading. Hedge fund returns are not normally distributed, and a general approach including higher moments is more appropriate. The Omega measure, proposed by Keating and Shadwick in 2002, is simple performance statistics that includes all the distribution moments of a time series.

$$
\Omega(\tau)=\frac{\int_{\tau}^{b}(1-F(x)) \mathrm{d} x}{\int_{a}^{\tau} F(x) \mathrm{d} x}
$$

where $F(x)$ is the cumulative density function and $\tau$ the minimum acceptable return (MAR). This measure better models the shape of the asymmetric distribution of hedge funds returns. The asymmetric nature of the distribution invalidates one of the major assumptions behind all traditional Markowitz-based models.

As defined in the function above, returns series is divided into gain and loss according to a MAR $(\tau)$, which is the benchmark return.

arbitrage). It is the analysis of complex combinations of all these factors that determines the final asset allocation of any hedge fund portfolio.

In this specific topic of asset allocation, there is still some progress to be made. Researchers have started to develop sophisticated models such as Omega, which decomposes the historical distribution of hedge fund returns (Box 7), ${ }^{8}$ but these optimisation methodologies do not work or have shown less attractive results than they do in equity/fixed income asset classes. As discussed earlier, volatility contains only limited information about the future. As an example, in 2004, all optimisers would have recommended an overweight in convertible bonds thanks to their past risk/return profile. This would have been a mistake as this strategy was starting to suffer from high capacity issues. Thus, only a combination of understanding how the risks behave in a strategy/hedge fund combined with investor views of the future will grant a higher potential return. Allocations obtained from optimisers remain informative, but judgmental analysis is more important to build a portfolio turned towards the future.
In summary, when building a portfolio of hedge funds today one must verify a combination of two elements. First, how serious is due diligence conducted on the components of the hedge fund portfolio? Has the due diligence team identified all the operational, credit and market risks in the hedge funds in which it invests? Second, how developed is the portfolio construction? Does the number of managers constituting the hedge fund portfolio represent an equivalent number of alphas? One must examine whether there exists a good understanding of the risks associated with each alpha and whether this is implemented into a general portfolio approach turned towards the future.

\section{Conclusion}

The objective of this article has been to revisit the negative press surrounding hedge funds in past years, and evaluate its validity in today's context. While we acknowledge that there are some risks associated with hedge funds, we believe that hedge fund investing has been 
largely misrepresented by the press, and its risks have been grossly exaggerated over the past several years. Furthermore, many of the concerns cited by the press, which were valid some years ago, are no longer founded. It is true that hedge fund investing has some risks (as does investing in bonds and equities), but these risks can be greatly reduced through a combination of in-depth due diligence and good portfolio construction.

Some investors have up to 75 per cent of their assets in hedge funds. This is not the case for all investors, but we believe that it is important to have a significant portion of any portfolio invested in hedge funds. Hedge funds can fulfil several roles in a wider portfolio. Some invest to have an uncorrelated return, to participate in bull equity markets while preserving downside risk, to get exposure to emerging markets through regional specialists, etc. It is, therefore, important to consider the intended objective of a hedge fund prior to making an investment. Hedge funds have multiple sources of alpha, and it is up to the investor to define the objective of his hedge fund investment.

\section{References}

1 Botteron, P. and Feiger, G. (2000) 'Should You, Would You, Could You Invest in Hedge Funds?' The Capco Journal, pp. 57-65.

2 Lhabitant, F. -S. (2002) 'Hedge Funds, Myths and Limits', John Wiley \& Sons, Ltd: New York.

3 Christory, C., Daul, S. and Giraud, J. -R. (2006). 'Quantification of Hedge Fund Default Risk', (forthcoming in Journal of Alternative Investment, December 2006 edition), December Edition.

4 Botteron, P. (2002). 'Investing in Hedge Funds, Survey on the Risk Approach Adopted by the Swiss Marketplace', Andersen, Switzerland.

5 Botteron, P. and Villiger, R. (2003). 'Risks in Hedge Funds Investments, in Hedge Funds: Strategies, Risk Assessment, and Returns', Beard Books: New York.

6 TASS Investment Research Ltd. and Tremont Partners, Inc. (2001). 'The Case for Hedge Funds', 2nd edn.

7 Fung, W. and Hsieh, D. (2000) 'Performance Characteristics of Hedge Funds and CTA Funds: Natural Versus Spurious Biases', Journal of Financial and Quantitative Analysis, Vol. 10, No. 3, pp. 291-307.

8 Keating, C. and Shadwick, W. (2002) 'A Universal Performance Measure', Journal of Performance Measurement', Spring pp. 59-84. 